\title{
PERANAN BUDAYA ORGANISASI DAN KOMPETENSI KERJA TERHADAP KINERJA ORGANISASI PADA KOPERASI DI KOTA SEMARANG
}

\author{
Bagus Gumelar \\ Universitas Ahmad Dahlan \\ bagus.gumelar@mgm.uad.ac.id
}

\begin{abstract}
This study analyzed the influence of the role of organizational culture, work competence on organizational performance in cooperatives in the city of Semarang. The problem of this research is the decrease in net profit (SHU) of the cooperative legal entity in Semarang city during the period of 2013 until 2014. Profit decrease (SHU) in 2014 reached 28\% from 2013. The ability of cooperatives in obtaining profit (SHU) resulted in the profitability of cooperatives in the city of Semarang down and down also its performance. This study focuses on examining the effect of organizational culture and organizational competence on organizational performance. The result of a hypothesis test is done there is a significant and positive influence of organizational culture variable and work competence together to the performance of a cooperative organization in Semarang City either partially or simultaneously.
\end{abstract}

Keywords: organizational culture, work competence, organizational performance

\section{PENDAHULUAN}

Di era globaisasi ini perusahaan menghadapi tekanan-tekanan untuk berubah, mereka dituntut untuk menyesuaikan diri agar tetap bertahan dan sukses dalam persaingan bisnis saat ini dan yang akan datang. Meningkatnya persaingan bisnis mengharuskan perusahaan memformulasikan strategi yang inovatif, fleksibel, dan tanggap dalam merespon perubahan yang terjadi. Strategi adalah alat yang sangat penting dalam mencapai keunggulan bersaing. Manajer perlu menentukan bagaimana perusahaan bisa menciptakan keunggulan kompetitif yang tidak hanya unik dan berharga, tetapi juga sulit ditiru atau dicari subtitusinya sehingga mampu bertahan lama. Salah satu strategi yang bisa dilakukan perusahaan adalah peningkatan kualitas kompetensi sumber daya manusia.
Kompetensi berhubungan dengan kemampuan seseorang dalam melaksanakan suatu pekerjaan dengan berdasarkan pengalaman, dan keahlian. Kompetensi merupakan kumpulan sumber daya manusia yang secara dinamis menunjukkan kapasitas intelektual, kualitas sikap mental dan kapabilitas sosial seseorang.

Dalam rangka mencapai tujuan koperasi, diperlukan suatu sumber daya manusia perkoperasian yang profesional melalui perangkat organisasi yang ada. Peranan pengurus, pengelola, dan pengawas koperasi yang kompeten diperlukan dikarenakan tanggung tawab pengelolaan koperasi yang telah diamanatkan oleh anggota koperasi demi terwujutnya tujuan koperasi yaitu kesejahteraan anggota.

Untuk mencapai keunggulan kompetitif, manajemen sumber daya organisasi harus disesuaikan dengan strategi yang digunakan oleh organisasi. Oragnisasi perusahaan diharapkan 
Peranan Budaya Organisasi Dan Kompetensi Kerja Terhadap Kinerja Organisasi Pada Koperasi Di Kota Semarang

konsisten dalam penerapkan nilai-nilai budaya organisasi, kebijakan strategi baik mulai dari perencanaan sampai ke implementasinya untuk mampu mempengaruhi keseimbangan kompetitif bisnis, dan mengeksplorasi perubahan bisnis (Porter, 1985).

Koperasi Indonesia tertuang di dalam amanat Undang-undang dasar 1945 pasal 33 ayat 1 yang menyebutkan menyatakan bahwa perekonomian Indonesia disusun sebagai usaha bersama berdasar atas asas kekeluargaan. Sebagaimana kegiatan usaha lainya, koperasi adalah badan usaha yang beranggotakan orang-seorang atau badan hukum Koperasi dengan melandaskan kegiatannya berdasarkan prinsip koperasi sekaligus sebagai gerakan ekonomi rakyat yang berdasar atas asas kekeluargaan. (UU Republik Indonesia Tentang Perkoperasian Nomor $25 \mathrm{Ta}-$ hun 1992: Pasal 1 ayat 1). Uraian diatas dapat garis bawahi yaitu : Pertama koperasi beranggotakan orang-seorang dan badan hukum koperasi. Koperasi beranggotakan orang-seorang dibentuk dengan beranggotakan kumpulan orang minimal 20 orang untuk membentuk sebuah koperasi yang dinamakan koperasi primer (Undang-undang No. 25 tahun 1992, pasal 6 ayat 1 Tentang perkoperasiaan). Kedua koperasi terdiri badan hukum koperasi adalah koperasi yang terdiri dari minimal 3 badan hukum koperasi membentuk sebuah koperasi sekunder (Undang-undang No. 25 tahun 1992, pasal 6 ayat 2 Tentang perkoperasiaan).

Koperasi bertujuan untuk memajukan kesejahteraan anggota pada khususnya dan masyarakat pada umumnya serta ikut membangun tatanan perekonomian nasional dalam rangka mewujudkan masyarakat yang maju, adil, dan makmur berlandaskan Pancasila dan UndangUndang Dasar 1945. (UU Republik Indonesia Tentang Perkoperasian Nomor 25 Tahun 1992: Pasal 3). Kesejahteraan masyarakatlah yang diutamakan bukan kesejahteraan orang seorang yang sesuai dengan itu ialah koperasi. Konsep
Kemakmuran yang di jelaskan disini mempunyai arti yang sangat luas dan berbeda di antara anggota dalam suatu koperasi. Jika anggota koperasi memperoleh layanan dari koperasi secara murah, tepat, dan cepat dan hal itu sudah dianggap memakmurkan anggotanya itulah tujuan koperasi.

Kota Semarang memiliki badan hukum koperasi total 990 badan hukum koperasi terdiri dari 778 badan hukum koperasi aktif dan 202 badan hukum koperasi tidak aktif. (data keragaan koperasi triwulan 4 tahun 2015, Dinas Koperasi dan Usaha Mikro, Kecil dan Menengah Kota Semarang).

Koperasi aktif adalah koperasi yang berjalan mekanisme manajemen koperasi, seperti rapat anggota tahunan (RAT), audit, proses perencanaan, pengorganisasian, pelaksanaan dan pengawasan, aktivitas bisnis berjalan, dan ketaatan terhadap peraturan perundangan yang berlaku. (Peraturan Menteri Negara Koperasi Dan Usaha Kecil Dan Menengah Republik Indonesia Nomor: 22/PER/M.KUKM/IV/2007: pasal 4 ayat 1a).

\section{Tabel 1}

Data Perkembangan Koperasi Tahun 2013 Sampai Dengan Tahun 2014

\begin{tabular}{|l|c|c|c|}
\hline No. & Periode & Laba (SHU) & $\begin{array}{c}\text { Penurunan } \\
\text { Pesentase } \\
\text { SHU (\%) }\end{array}$ \\
\hline 1 & Tahun 2013 & 70.634 .272 .000 & \multirow{2}{*}{ Turun $28 \%$} \\
\hline 2 & Tahun 2014 & 51.112 .580 .000 & \\
\hline
\end{tabular}

Sumber: Data Keragaan Koperasi, Dinas Koperasi dan

UMKM kota Semarang tahun 2013 sampai tahun 2014

Dari data diatas menunjukkan bahwa ada penurunan SHU badan hukum koperasi di Kota Semarang sepanjang tahun 2013 sampai tahun 2014 mencapai 28\%. Perkembangan koperasi di Kota Semarang masih menghadapi kendalakendala baik dari kelembagaan dan usaha koperasi. Masalah-masalah tersebut dapat bersumber dari dalam koperasi sendiri maupun dari luar. 
Masalah intern mencakup masalah keanggotaan, kepengurusan, pengawas, manajer, dan karyawan koperasi. Sedangkan masalah ekstern mencakup hubungan koperasi dengan bank, dengan usahausaha lain, dan juga dengan instansi pemerintah.

Permasalahan dalam penelitian ini adalah adanya penuruan SHU badan hukum koperasi di kota semarang selama kurun waktu tahun 2013 sampai tahun 2014. Perununan pada tahun 2014 SHU mencapai 28\% dari tahun 2013. Murpy et al (1996) menyatakan bahwa profitabilitas suatu perusahaan mempengaruhi suatu kinerja perusaahan. Kemampuan koperasi dalam memperoleh SHU mengakibatkan profitabilitas koperasi di Kota Semarang turun dan turun pula kinerjanya.

\section{REVIEW LITERATUR DAN HIPOTESIS}

\section{Budaya Organisasi}

Budaya organisasi diartikan sebagai kesepakatan bersama dalam sebuah kehidupan organisasi dan mengikat semua orang dalam organisasi yang bersangkutan. Siagian (2007: 27). Menurut Pearce (2009:483) Budaya organisasi adalah sekelompok asumsi penting yang dipegang bersama oleh anggota-anggota suatu organisasi.

Budaya organisasi yang kuat akan menghasilkan kesepakatan bersama dalam organisasi yang kuat pula. Kultur organisasi harus dipahami antar anggota organisasi agar lebih lama dari keberadaan siapapun didialam organisasi tersebut. Pendapat lain juga dikemukakan Robbins (2015:355),

\section{Kompetensi Kerja}

Kompetensi berhubungan dengan kemampuan seseorang dalam melaksanakan suatu pekerjaan dengan berdasarkan pengalaman, dan keahlian. Kompetensi merupakan kumpulan sumber daya manusia yang secara dinamis menunjukkan kapasitas intelektual, kualitas sikap mental dan kapabilitas sosial seseorang. Mc Clelland (1973) yang menjelaskan ada sesuatu karakteristik dasar yang lebih penting dalam mempengaruhi kesuksesan kerja yaitu kompetensi. kompetensi itu, lebih penting daripada kecerdasan akademik. Kompetensi itu dapat ditentukan dengan akurat, dapat menjadi titik penentu (critical factor) pembeda antara sumber daya manusia yang mampu dan mau mengerjakan tugas dan pekerjaan yang dipercayakan kepadanya dan sumber daya manusia sudah tidak bisa lagi diharapkan produktivitasnya.

\section{Kinerja Organisasi}

Menurut Stolovitch and keeps (1992) dalam Abdullah (2005:14) kinerja merupakan seperangkat hasil yang dicapai dan merujuk pada tindakan pencapaian serta pelaksanaan suatu pekerjaan yang diminta.

Untuk mengkur kinerja yang biasa dilakukan dalam berbagai penelitian adalah pertumbuhan (growth), kemampuan organisasi atau perusahaan dalam menghasilkan laba (profitability) dan efisiensi (efficiency) (Murpy, et.al,1996).

Faktor pendorong kinerja adalah faktorfaktor khusus yahg terdapat pada unit bisnis tertentu yang didasarkan pada keunikan unit bisnis tertentu. Misalnya faktor pendorong financial dari profitabilitas, segmen pasar yang dipilih unit bisnis, serta tujuan proses internal, dan pembelajaran dan pertumbuhan tertentu. (Kaplan dan Norton, 1996:130).

\section{Hipotesis}

Berdasarkan penjelasan sebelumnya dapat dirumuskan hipotesis pada penelitian ini sebagai berikut:

$\mathrm{H}_{1}$ : Budaya organisasi berpengaruh positif terhadap kinerja organisasi

$\mathrm{H}_{2}$ : Kompetensi kerja berpengaruh positif terhadap kinerja organisasi 


\section{Kerangka Pemikiran Teoritis}

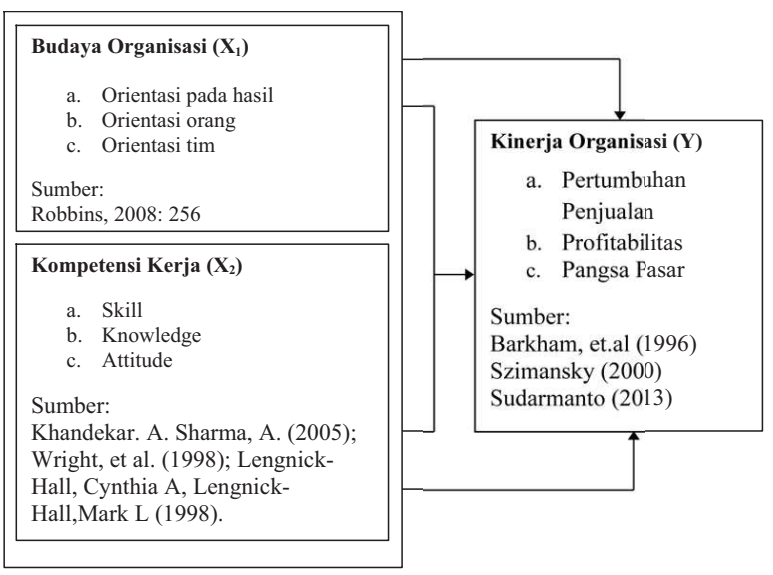

Sumber: dikembangkan dalam penelitian ini

Gambar 1. Kerangka Pemikiran

\section{METODE PENELITIAN}

Penelitian ini didasarkan pada penelitian kausalitas. Penenilian kausalitas adalah penelitian yang didasarkan pada hubungan sebab-akibat (cause-effect) atara beberapa variabel atau beberapa strategi yang dikembangkan dalam manajemen yang diarahkan untuk menggambarkan adanya hubungan sebab-akibat antara beberapa situasi dan ditariklah kesimpulan umum (Ferdinand, 2013: 7).

Ada dua jenis data yang digunakan pada penelitian ini, yaitu data primer dan data sekunder. Data primer dalam penelitian ini bersumber dari hasil kuesioner dari badan hukum koperasi di Kota Semarang, sedangkan data sekunder bersumber dari data-data keragaan badan hukum koperasi Dinas Koperasi dan UMKM Kota Semarang, data pemeringkatan koperasi berprestasi Kota Semarang, dan data penilaian kesehatan koperasi Kota Semarang.

Populasi yang digunakan dalam penelitian ini adalah koperasi yang telah dinilai kinerjanya dengan instrument pemeringkatan koperasi tahun 2015 yang dilaksanakan oleh Dinas Koperasi dan Usaha Mikro, Kecil dan Menengah Kota Semarang sebanyak 174 koperasi.

Teknik sampling dalam penelitian ini menggunakan purposive sampling dengan kriteria: koperasi yang memenuhi kriteria berkualitas. Berdasakan purposive sampling diperoleh sampel sejumlah 48 responden. Data didapat langsung dari responden dengan bantuan seperangkat kuesioner. Data dikumpulkan dengan memberikan daftar pertanyaan atau kuesioner kepada para pengelola koperasi. Pengumpulan data dilakukan dengan menggunakan satu macam angket yaitu angket tertutup. Pertanyaan-pertanyaan dalam angket tertutup dibuat dengan menggunakan skala $1-5$ untuk mendapatkan data yang bersifat interval dan diberi skor atau nilai sangat tidak setuju / sangat setuju.

Uji reliabilitas merupakan uji kehandalan yang bertujuan untuk mengetahui seberapa jauh sebuah alat ukur dapat diandalkan atau dipercaya. Pengujian reliabilitas pada penelitian ini akan menggunakan formula cronbach alpha (koefisien alfa (ronbach), dimana secara umum yang dianggap reliable apabila nilai alfa cronbachnya $>0,6$. Validitas menunjukkan sejauh mana suatu alat ukur itu mengukur construct yang akan diukur menggunakan metode korelasi Product Moment Pearson. Suatu alat ukur dikatakan valid jika Corrected item total correlation lebih besar atau sama dengan 0,41 (Santoso, 2000)

Teknik analisis penelitian ini menggunakan analisis jalur yang dikembangkan dalam kerangka penelitian Analisis regresi linear berganda dari paket software statistik SPSS digunakan dalam pengembangan model dan pengujian hipotesis. 


\section{HASIL PENELITIAN DAN PEMBAHASAN}

\section{Karakteristik Responden}

Berdasarkan kuesioner yang dibagikan semuanya terkumpul sejumlah 48 responden yang kesemuanya berjabatan Manajer atau Pengurus Koperasi di Kota Semarang. Adapun rangkuman karakteristik responden dalam penelitian ini adalah:

\section{Tabel 2}

\section{Karakteristik Responden}

\begin{tabular}{|c|c|c|}
\hline $\begin{array}{c}\text { Karakteristik } \\
\text { Responden }\end{array}$ & Jumlah & Persentase (\%) \\
\hline $\begin{array}{c}\text { Jenis kelamin } \\
\text { Laki-laki }\end{array}$ & 28 & $58 \%$ \\
\hline Perempuan & 20 & $42 \%$ \\
\hline Tingkat Pendidikan & & $17 \%$ \\
\hline Diploma & 8 & $77 \%$ \\
\hline Sarjana & 37 & $6 \%$ \\
\hline Magister & 3 & $25 \%$ \\
\hline Usia Koperasi & 12 & $29 \%$ \\
\hline 1 tapun & 14 & $46 \%$ \\
\hline 1-3Tahun 3 tahun & 22 & $42 \%$ \\
\hline Jumlah Tenaga Kerja & 20 & $54 \%$ \\
\hline $1-4$ orang & 26 & $4 \%$ \\
\hline $5-19$ grang & 2 & \\
\hline $20-99$ orang & & \\
\hline Sum & & \\
\hline
\end{tabular}

Sumber: data diolah, 2017

\section{Uji Normalitas}

Uji Multikolonieritas bertujuan untuk menguji apakah model regresi ditemukan adanya korelasi antar variabel bebas (independen). Model regresi yang baik seharusnya tidak terjadi korelasi antar variabel independen.

Berdasarkan hasil uji normalitas kolmogorov-smirnov terlihat dari nilai Asymp. Sig. (2-taied) sebesar 0.854 atau probabilitas $>0,05$ maka data penelitian berdistribusi normal.

\section{Uji Multikolinieritas}

Uji Multikolonieritas bertujuan untuk menguji apakah model regresi ditemukan adanya korelasi antar variabel bebas (independen). Mod- el regresi yang baik seharusnya tidak terjadi korelasi antar variabel independen. Variabel bebas tidak mengalami multikolinieritas jika a hitung $>$ a dan VIF hitung lebih <VIF. Nilai cutoff yang umum dipakai untuk menunjukkan adanya multikolinearitas adalah nilai tolerance $<0.10$ atau sama dengan nilai VIF $>10$.

Berdasarkan hasil uji multikolinearitas, hasil perhitungan VIF menunjukkan hasil tidak ada variabel yang memilki nilai VIF lebih dari 10 dan Nilai tolerance tidak ada yang kurang dari 0,10 yang berarti tidak ada korelasi antar variabel bebas. Jadi dapat disimpulkan bahwa tidak ada multikolinearitas antar variabel bebas dalam model regresi.

\section{Uji Heteroskedastisitas}

Uji heteroskedastisitas bertujuan menguji apakah dalam model regresi terjadi ketidaksamaan variance dari residual satu pengamatan ke pengamatan yang lain. Tidak terjadi heteroskedastisitas jika pada sactterplot titik-titik hasil pengolahan data lewat program SPSS antara ZPERD (sumbu $\mathrm{X}=\mathrm{Y}$ hasil predisksi) dan SRESID (sumbu Y-Y prediksi - Y riil) menyebar di bawah ataupun di atas titik origin (angka 0) pada sumbu Y dan tidak mempunyai pola yang teratur.

Berdasarkan hasil uji heteroskedastisitas, bahwa tidak ada pola yang jelas dan titik-titik menyebar diatas dan dibawah angka nol pada sumbu Y, maka dapat disimpulkan bebas heteroskedastisitas sehingga model regresi dapat dipakai untuk memprediksi kinerja organisasi berdasarkan masukan variabel bebas atau independen yaitu budaya organisasi dan kompetensi kerja.

\section{Uji Autokorelasi}

Uji autokorelasi bertujuan untuk menguji apakah dalam model regresi liniear ada korelasi antara kesalahan periode t-1 (sebelumnya). Jika terjadi korelasi, maka dinamakan ada problem autokorelasi. Untuk mendeteksi ada tidaknya autokorelasi digunakan uji Durbin-Watson (DW 
Peranan Budaya Organisasi Dan Kompetensi Kerja Terhadap Kinerja Organisasi Pada Koperasi Di Kota Semarang

test).

Nilai Durbin Watson (DW test) adalah 1.983. Berdasarkan tabel Durbin Watson besarnya dL adalah 1,4500 dan besarnya dU adalah 1,6231. Tidak terjadi autokorelasi jika DW terletak antara batas auatu dU dan 4-dU. Hasil penelitian ini DW terletak antara du $(1,6231)$ dan (4$1,6231=2,377)$ dapat disimpulkan bahwa tidak ada masalah autokorelasi pada penelitian ini.

\section{Pengujian Hipotesis}

\section{Uji Simultan (Uji F)}

Uji simultan digunakan untuk mengetahui pengaruh dari variabel bebas terhadap variabel terikat secara bersama sama. Uji ANOVA atau F test di dapat dari nilai $\mathrm{F}$ hitung sebesar 32.716 dengan tingkat signifikasi 0.000 . karena probabilitas signifikan jauh lebih kecil dari 0.05 maka Ho di tolak dan Ha diterima, Hal ini menunjukan bahwa ada pengaruh secara simultan antara budaya organisasi dan kompetensi kerja secara bersama-sama terhadap kinerja.

\section{Uji Parsial (Uji t)}

Untuk mengetahui pengaruh variabel bebas budaya organisasi, kompetensi kerja terhadap variabel terikat yaitu kinerja organisasi maka perlu dilakukan uji t. Hasil uji parsial dapat dilihat pada tabel berikut ini:

\section{Tabel 3}

\section{Hasil Pengujian Hipotesis}

\begin{tabular}{|c|c|c|c|c|}
\hline Hipotesis & $\begin{array}{c}\text { Standardized } \\
\text { coefficients } \\
\text { beta }\end{array}$ & $\mathbf{T}$ & Sig. & Kesimpulan \\
\hline Hipotesis 1 & 0,350 & 2,412 & 0,020 & Terdukung \\
\hline Hipotesis 2 & 0,471 & 3,244 & 0,002 & Terdukung \\
\hline
\end{tabular}

Sumber: data diolah, 2017

Berdasarkan hasil uji parsial (uji t) untuk budaya organisasi diperoleh t hitung sebesar 2.412 dengan nilai signifikansi 0.020 . Karena nilai signifikansi jauh lebih kecil dari 0,05 maka Ho ditolak, hal ini menunjukan bahwa $\mathrm{H}_{1}$ yang menyatakan "ada pengaruh yang signifikan antara budaya organisasi terhadap kinerja organisasi”.

Berdasarkan hasil uji parsial (uji t) untuk variabel kompetensi kerja diperoleh thitung sebesar 3.224 dengan nilai signifikansi 0.002. Karena nilai signifikansi jauh lebih kecil dari 0,05 maka Ho ditolak, hal ini menunjukan bahwa $\mathrm{H}_{2}$ yang menyatakan "ada pengaruh yang signifikan antara Kompetensi kerja terhadap kinerja organisasi”.

\section{Koefisien Determinasi Simultan}

Untuk mengetahui besarnya kontribusi budaya organisasi dan kompetensi kerja terhadap kinerja organisasi secara simultan dapat diketahui berdasarkan nilai Adjusted $R$ Square pada tabel Model Summary diketahui bahwa nilai Adjusted $R$ Square sebesar 0,574 Sehingga dapat disimpulkan bahwa kontribusi budaya organisasi dan kompetensi kerja terhadap kinerja secara simultan adalah 57,4\%.

\section{Koefisien Determinasi Parsial}

Berdasarkan hasil perhitungan dengan menggunakan program SPSS diketahui bahwa besarnya koefisien antara $\mathrm{X}_{1}$ terhadap $\mathrm{Y}$ sebesar 0,338 sehingga dapat diketahui bahwa besarnya pengaruh $\mathrm{X}_{1}$ terhadap $\mathrm{Y}$ sebesar $(0,338)^{2}$ sama dengan 0,1142 atau $11,42 \%$. Besarnya koefisien antara $\mathrm{X}_{2}$ terhadap $\mathrm{Y}$ sebesar 0,435 sehingga dapat diketahui bahwa besarnya pengaruh $\mathrm{X}_{2}$ terhadap Y sebesar $(0,435)^{2}$ sama dengan 0,189 atau $18,92 \%$.

\section{KESIMPULAN DAN SARAN}

Hasil uji hipoteses yang dilakuan terdapat pengaruh yang signifikan dan positif dari variabel budaya organisasi dan kompetensi kerja secara bersama sama terhadap kinerja organisasi koperasi di Kota Semarang baik secara parsial maupun simultan. Hasil penelitian ini menunjukkan nilai 
F hitung 32,716 dengan nilai signifikansi 0,000. Dengan demikian signifikansi $(0,000)<(0,05)$, sehingga Ha diterima dan Ho di tolak. Adapun pengaruh budaya organisasi dan kompetensi kerja terhadap kinerja organisasi Koperasi di Kota semarang dilihat dari nilai Adjusted $R$ Square dan di dapat nilai sebesar 0,574 . Hal ini menunjukan bahwa budaya organisasi dan kompetensi kerja berpengaruh secara simultan terhadap kinerja organisasi sebesar 57,4\% dan 42,6\% lainya di pengaruhi oleh faktor faktor yang lain selain variabel budaya organisasi dan kompetensi.

Dari uji parsial yang diperoleh dari hasil terdapat pengaruh yang signifikan dari variabel budaya organisasi terhadap kinerja organisasi. Hal ini dibuktikan dari hasil penelitian yang menunjukkan nilai t hitung 2,412 dengan nilai signifikansi 0,020 jauh lebih kecil dari 0,05, sehingga Ha yang berbunyi "ada pengaruh budaya organisasi terhadap kinerja organisasi pada koperasi di Kota Semarang" diterima. Variabel kompetensi SDM juga menunjukkan hal yang sama dengan t hitung 3,224 nilai signifikansi 0,002 sehingga menerima Ha yang berbunyi "ada pengaruh kompetensi kerja terhadap kinerja organisasi pada koperasi di Kota Semarang” Menurut Hasil koefisien determinasi secara parsial diketahui bahwa kontribusi dari pengaruh budaya organisasi terhadap kinerja organisasi pada koperasi di Kota Semarang sebesar $11.42 \%$. besarnya pengaruh kompetensi kerja terhadap kinerja organisasi pada koperasi di Kota Semarang sebesar 18,92\%.

\section{DAFTAR PUSTAKA}

Adu, Appiah. 2001. Marketing effectiveness and business performance in the financial services industry. Santa Barbara: Emerald Group Publishing.

Alsughayir, Abdulrahman. 2014. Human Resource Strategies as a Mediator between
Leadership and Organizational Performance. International Business Research; Vol. 7, No. 3.

Barkham, R; Gudgin, G; Hart, M dan Hanvey, E (1996a) The Determinans of Small Firm Growth. Jessica Kingsley: London

Barkham, R; Hart, M dan Hanvey, E (1996b) Growth in Small Munufacturign Firms: an empirical analysis. Paul Chapman Publishers: London

Barney, J. B. 1991. Firm Resources and Sustained Competitive Advantage. Journal of Management.

Bass, B.M. dan Avolio, 1997, "Does The Transactional - Transformational Leadership Paradigm Transcend Organizational and National Boundaries?", Journal American Psychologist, 52: 130-139

Budhiraja, Sunil. Malhotra, Meenakshi. 2013. Leadership Style \&Orgaiiizational Effectiveness in Indian IT \& Banking Industry. The Indian Journal of Industrial Relations, Vol 49, No. 2

Chheda, Kavan. 2013. Impact of Entrepreneurial Leadership on Performance of Small and Medium Enterprises in India. Journal of Asia Entrepreneurship and Sustainability Vol XI Iss 2.

Chi, Hsinkuang. Lan, Chun-Hsiung \& Battogtokh Dorjgotov, 2011. The Influences of Organizational Culture and Human Resource Development on R\&D organizational Effectiveness - the Mediating Effect of Knowledge Management. Taiwan: Nanhua University.

Chow, Irene Hau S dan Liu S.S. 2009. The effect of aligning organizational culture and business strategy with HR systems on firm performance in Chinese enterprises. The International Journal of Human Resource Management,Vol. 20, No. 11. 
Peranan Budaya Organisasi Dan Kompetensi Kerja Terhadap Kinerja Organisasi Pada Koperasi Di Kota Semarang

Dana M. Cosby. 2014, Sustainability Program Leadership for Human Resource Development Professionals: A Competency Model, Journal of Organizational Culture, Communications and Conflict, Volume 18, Number 2.

Davis, Peter S, dan Pett, Timothy L. 2002. Measuring Organizational Efficiency and

Effectiveness. Journal of Management Research. Ebsco Publishing.

Denison, D.R. \& Mishra, A.K. 1995. Toward a Theory of Organizational Culture and Effectiveness. Organization Science, Vol. 6, No. 2 (Mar. - Apr., 1995).

Ellitan, Lena. 2002. Praktik-Praktik Pengelolaan Sumber Daya Manusia dan Keunggulan Kompetitif Berkelanjutan. Jurnal Manajemen dan Kewirausahaan Vol. 4.

Flaherty, M.T. 1996. Global Operation Management. New York: McGraw Hill, Inc.

Ferdinand, Augusty. 2013. Metode Penelitian Manajemen. Semarang: Undip Press

2014. Structural Equation Modeling. Semarang: Undip Press

Gibson, James. L. 1995. Organisasi. Jakarta: Erlangga

Hair, J. F., Jr., Anderson, R. E., Tatham, R. L. and Black, W. C.1995. Multivariate Data Analysis, 3rd ed, Macmillan Publishing Company, New York.

Harwiki, Wiwiek. 2013. The Influence of Servant Leadership on Organization Culture, Organizational Commitment, Organizational Citizenship Behavior and Employees' Performance (Study of Outstanding Cooperatives in East Java Province, Indonesia). Journal of Economics and Behavioral Studies.

Jung, Yuhee . Takeuchi , Norihiko. 2010. Perfor- mance implications for the relationships among top management leadership, organizational culture, and appraisal practice: testing two theory-based models of organizational learning theory in Japan. The International Journal of $\mathrm{Hu}-$ man Resource Management, Vol. 21, No. 11

Ketchen, Jr. D. et al. 2009. Strategy 2008-2009. New York: McGraw-Hill

Loshali, Surabhi. Krishnan, Venkat R. 2013. Strategic human resource Management and firm performance: Mediating role of Transformational leadership. Journal of Strategic Human Resource Management Volume 2 Issue 1.

Méndez, Martínez R. Muñoz, Vera JGS. \& María Antonieta M. 2013. Leadership Styles and Organizational Effectiveness in Small Construction Businesses in Puebla, Mexico. Global Journal of Business Research.

Murphy, Gregory B. Jeff W. and Robert C. 1996. Trailer, Measuring performance in entrepreneurship research. Hill Journal of Business Research. vol. 36. issue 1

Romano, Kenneth W. 2004. The Influence of Organizational Culture, Leadership, and Structure on Operational Effectiveness in The Aerospace Industry. ProQuest Information and Learning Company

Porter, Michael, E. 1996. What is Strategy?. Harvard Business Review.

Prahalad, Garry Hamel. 1990. The Core Competence of Corporation, Harvard Business Review.

Puni, Albert. Ofei, Samuel B \& Abednego Okoe. 2014. The Effect of Leadership Styles on Firm Performance in Ghana. International Journal of Marketing Studies; Vol. 6, No. 1 
Robbins, Stepen, P, dan Timothy A Judge. 2015. "Organizational bahaviour". Jakarta: Salemba Empat

Robbins, Stephen P., 2001, Perilaku Organisasi, Konsep, Kontroversi, Aplikasi,

Edisi Bahasa Indonesia Jilid 1, PT. Prenhallindo, Jakarta

Robbins, Stephen P. 2002. Perilaku Organisasi. Edisi 5. Alih Bahasa: Halida, Dewi Sartika. Jakarta: Erlangga.

2008. Perilaku Organisasi. Buku 2. Edisi 12. Alih Bahasa: Diana angelica, dkk. Jakarta: Salemba empat.

Santa, Ricardo \& Ferrer, Mario. 2009. The necessary alignment between technology innovation effectiveness and operational effectiveness. Journal of Management \& Organization.

Schein, Edgar H. 2004. Organizational culture and leadership. San Francisco: JosseyBass A Wiley Imprint.

Shahzad, Fakhar. 2012. Impact of Organizational Culture on Organizational Performance: An Overview, Interdisciplinary Journal of Contemporary Research In Business, Vol 3, No 9.

Shaw, Doris M. 2005. Sales Effectiveness and Firm Performance : A Small Prespective. The Entrepreneurial Executive ProQuest Research Library

Steers, R. 1975. Problems in the Measurement of Organizational effectiveness. Administrative Science Quarterly.

Sumarsono, Sonny. 2004. "Metode riset sumber daya manusia”. Yogyakarta : Graha ilmu

Wang, Dan-Shang. Shyu Chi-Lih. 2008. Will the strategic fit between business and HRM strategy influence HRM effectiveness and organizational performance? International Journal of Manpower: Emerald Group Publishing Limited Vol. 29 No. 2.

Zheng,W., Yang,B. 2005. The Impact of Organizational Culture, Structure, and Strategy on Knowledge Management Effectiveness and Organizational Effectiveness. Journal of Business Research. 
BAGUS GUMELAR

Peranan Budaya Organisasi Dan Kompetensi Kerja Terhadap Kinerja Organisasi Pada Koperasi Di Kota Semarang 